\title{
Handling a crisis via a combination of human initiative and godly direction: Insights from the Book of Ruth
}

\author{
Author: \\ Robin Gallaher Branch ${ }^{1,2}$ \\ Affiliations: \\ ${ }^{1}$ Faculty of Theology, \\ North-West University, \\ Potchefstroom Campus, \\ South Africa \\ ${ }^{2}$ Victory University, Memphis, \\ Tennessee, USA \\ Correspondence to: \\ Robin Gallaher Branch \\ Email: \\ rgbranch@victory.edu \\ Postal address: \\ 255 North Highland, Victory \\ University, Memphis, \\ Tennessee, USA \\ 901-320-9700 x 1091

\section{Dates:} \\ Received: 19 Nov. 2010 \\ Accepted: 02 Aug. 2011 \\ Published: [to be released] \\ How to cite this article: \\ Branch, R.G., 2012, 'Handling \\ a crisis via a combination of \\ human initiative and godly \\ direction: Insights from the \\ Book of Ruth', In die Skriflig/ \\ In Luce Verbi 46(2), Art \#110, \\ 11 pages. http://dx.doi.org/ \\ 10.4102/ids.v46i2.110
}

Note:

This article continues work I started in my book on biblical women and girls who exhibit great courage (see Branch 2009). Courageous children in the book include Miriam (Ex 2:1-10) and the Israelite slave girl (2 Ki 5:1-14). Courageous women in the book include Rizpah (2 Sam 21:1-14), the Wise Woman of Abel Beth Maacah (2 Sam 20:14-22) and the Widow of Zarepath (1 Ki 17:1-24).

(C) 2012. The Authors. Licensee: AOSIS OpenJournals. This work is licensed under the Creative Commons Attribution License.
The biblical text introduces Ruth, a Moabite woman, at a time of personal crisis. She faces destitution. Life has handed her multiple blows, amongst them widowhood and childlessness. Her single asset? Naomi, a cranky, elderly but endearing mother-in-law. Naomi, an Israelite and also widowed, is now quite determined to go home to Bethlehem. Ruth joins Naomi's journey, but for Ruth it is a pilgrimage, for it is at this time that she switches allegiance from the gods of Moab to the God of Israel. As an immigrant facing change on every level - a new culture, a new religion, no friends and no job - Ruth nonetheless triumphs. Within only a couple of months, not only does she marry a prominent and prosperous bachelor, Boaz, but also wins the hearts of her mother-in-law's friends, the women of Bethlehem. This analysis of her successful pilgrimage offers contemporary guidelines for facing dramatic changes. Using a literary method, this article examines one of the Bible's accounts of how a personal crisis is resolved via a combination of God's providence and human initiative and courage.

Die hantering van 'n krisis deur 'n kombinasie van menslike inisiatief en goddelike bestuur: Insigte uit die boek Rut. Die bybelse teks stel die leser voor aan Rut, 'n Moabitiese vrou, tydens ' $n$ persoonlike krisis in haar lewe. Sy is ' $n$ weduwee, kinderloos en staar dus armoede in die gesig. Haar enigste pluspunt is Naomi, haar bejaarde, ietwat verbitterde dog innemende skoonmoeder. Naomi, 'n Israeliet en ook 'n weduwee, is vasbeslote om na haar huis in Betlehem terug te keer. Rut vergesel haar en dit word vir Rut 'n pelgrimstog na die God van Israel, weg van die afgode van Moab af. As immigrant wat 'n vreemde kultuur en godsdiens, 'n toekoms sonder vriende en werkloosheid moet verwerk, seëvier Rut uiteindelik. Sy trou binne ' $n$ paar maande met Boas, 'n prominente en welvarende vrygesel en wen ook die harte van haar skoonmoeder se vriendinne, die vroue van Bethlehem. Die ontleding van Rut se suksesvolle pelgrimstog bied tydgenootlike riglyne aan diegene wat voor groot veranderinge in hulle lewens te staan kom. Met behulp van die literêre metode ondersoek hierdie artikel ' $n$ bybelse mededeling wat aantoon hoedat ' $n$ persoonlike krisis deur middel van God se voorsienigheid en menslike inisiatief en moed opgelos kan word.

\section{Introduction}

One day several years ago when I was teaching seminary students biblical Hebrew and using the Book of Ruth as an example, I stopped in the middle of a discussion on some thorny Hebrew verb problems and said, 'You know, class, the Book of Ruth, a story set in the time of the Judges, shows us how to begin a new season in life. For instance, Ruth, a Moabite woman, gives us guidelines on facing new challenges and handling them well' (see Bush 1996:37; Iser 1980:51). ${ }^{1}$ The students (delighted to have a break from Hebrew and to be able to converse in English again) listened to my insights and brainstormed some of their own. Indeed, the Book of Ruth (when read through the lens of a national catastrophe such as a famine) and the woman Ruth (when seen through the lens of immigration and personal crises such as bereavement, childlessness, the struggle to survive and unemployment) provide examples of how to live successfully after experiencing major losses. One scholar goes so far as to say that a theme in the Book of Ruth is imitation. In other words, 'Go and do thou likewise' (Bush 1996:53). ${ }^{2}$ Go and live boldly like Ruth!

Other scholars see Ruth and the book named after her differently, of course. Bush (1996:55) notes that a major theme is surprises; God brings about surprises through ordinary events in life. Jordaan (2006:7) looks at the Book of Ruth via narrative therapy, a discipline that does not see

1.A good story (and the Book of Ruth is a masterfully written story based on real people and historical circumstances) contains the following elements: setting, characters, conflict or problems, complications, resolving the incidents, denouement, and conclusion (see ( Bush 1996.37). This article takes a literary approach to the Book of Ruth. A modern aspect of literary analysis is reader-response. Iser 1980.51), a proponent of reader-response, encourages imagination wh. A reading a text; when thus engaged, imagination enables the reader a propone through imagination; yet imagination must be kept within the boundaries of the text. Several times in this article I emphasise magination and yet advise that it be kept within the text's parameters.

2.Bush (1996:53) believes a message of the Book of Ruth is to imitate Ruth's conduct. 
a person as a problem but a problem as a problem. Loader (1994:25) sees the Book of Ruth as exemplifying the presence of a matriarch who fulfils the important roles of bringing together Boaz and Ruth and of providing security for herself and her daughter-in-law. Masenya (2004:46) emphasises that Ruth and Naomi become the agents advocating their own survival; their story speaks to modern African women who likewise struggle in their efforts to cope with emptiness and poverty. Sakenfeld (2002:164) believes that in no way is the Book of Ruth an idyllic tale; instead it confronts readers with the reality of women's suffering bodies. The traditional rabbinic interpretation is that Ruth asks God to repay her according to her deeds ('Ruth, Book of' 1971). Van Dyk and Van Dyk (2002:2009) connect the extraordinary suffering of Ruth and Naomi as women in the Book of Ruth to similar suffering of HIV and AIDS affected women in Africa. Martin (2008:505) cites similarities to, and marked differences with, the courtship and betrothal of Boaz and Ruth and other romances in the biblical text. Seeing a theological purpose, Bland (1981:129) states that 'a presentation of God's activity in man's daily routine of life is the predominant theme ... of the book of Ruth'. Siquans (2009:443) argues that the book's most important topics 'are foreignness and the acceptance of foreigners by Judahite society'. Westermann (1999:285) believes the book continues the biblical tradition of 'family narratives that celebrated the daring undertakings of independent women who, in threatening situations, seized the initiative to find a solution'. Bauckham (1997:35) says the story combines both female and male perspectives; it contrasts them, too, in, for example, the sections on the struggles of the two women and then in the congratulatory remarks of the people (dominantly men) given to Boaz on his marriage to Ruth. Ostriker (2002:357) calls the Book of Ruth an extraordinary 'erasure of the boundary between one's own people and the enemy'. Fewell and Gunn (1989:48) offer insights on the motives of Boaz: he wants to maintain his position in society, act responsibly and marry Ruth, whom he greatly desires.

Ruth and the book named after her are relevant today when unemployment in America stands at $9.2 \%{ }^{3}$ and home foreclosures run in the millions. ${ }^{4}$ Meanwhile in South Africa, unemployment stands officially at $25 \% .^{5}$ A third of South Africans live on less than R14 per day, about $\$ 2$ per day. ${ }^{6}$ On a worldwide level, unemployment rose from 178 million to 212 million in late 2009 because of the global economic crisis that started in 2007.7 Clearly, the Book of Ruth and Ruth's own immigration to a new land can speak to us today (see Eagleton 1991:76). ${ }^{8}$ A text such as the Book of Ruth

3.At the time this article was presented in Stellenbosch, unemployment in America was $8.5 \%$. This article was presented as a paper in June 2009 in Stellenbosch, South Africa, at a conference of a colloquium of societies that included SASNES (South African Society of Near Eastern Studies) and OTSSA (Old Testament Society of South African Soci
Africa).

4.According to Bloomberg (Bloomberg News Service 2011), a web news service, a record of 2.87 million properties in the United States received notices of default in 2010.

5.See South Africa Unemployment (Trading Economics, n.d.).

6.See CoinMill.com, (n.d). See Perry (2009).

7.World's Unemployment Rates 2006-2010 (Global Finance n.d.).

8.Eagleton (1991:76) points out that the reader of a text 'makes implicit connections, fills in gaps, draws inferences and tests out hunches; and to do this means drawing on a tacit knowledge of the world in general and of literary conventions in particular'. I allowed the Book of Ruth to engage me as I read and re-read the text. invites participation because it can evoke memories, create expectations and form conclusions that are personal for a reader (see Hansbury 1986:4). The Book of Ruth invites readers and hearers to come into the text (see Bauckham 1997:42). ${ }^{9}$

This article examines aspects of Ruth's character that emerge when she faces major transitions in life. These aspects include forming a strategy for facing dramatic change, her consistent work ethic, her willingness to take on the lowest job in town, her lifestyle that allows for no ugly gossip, her decision to adapt to her new environment, her relationship with her mother-in-law (see Westermann 1999:301) ${ }^{10}$ and her choice to keep her opinions to herself (see Greenblatt 2006:A66). ${ }^{11}$ Other aspects of her character that are discussed are her humility, courtesy and humour. We will see how she rises out of poverty and achieves status in her new land (see Siquans 2009:452). ${ }^{12}$ When flirted with, she flirts! Significantly, her pilgrimage starts with her conversion to Israel's God. Indeed, her lonely decision to take the hard path and accompany her mother-in-law led others, including the narrator of the Book of Ruth and God, to honour her (see Lostracco \& Wilkerson 1998:1). ${ }^{13}$ Significantly, the Book of Ruth remains consistent with the overall practice of the biblical canon for it gives few physical details describing Ruth and other characters (see Linafelt 2010:117-118). ${ }^{14}$ Although Ruth's story ends happily, or at least with a guarantee of provision for herself and Naomi, the birth of a son (see Sutskover 2010:283), ${ }^{15}$ the respect of other women and the unexpected honour of being in the line of David the king, it is not an idyllic tale (see Roop 2002:17). ${ }^{16}$

9.Bauckham (1997:42) writing on the Book of Ruth but commenting on its narrative similarity with the Gospels, notes that '... for the most part the Gospel narratives do not invite their readers or hearers to identify with Jesus' perspective on events. Rather the readers and/or hearers are invited to adopt successively the many Rather the readers and/or hearers are invited to adopt successively the many
different perspectives of those who hear, observe, encounter and follow Jesus'. The different perspectives of those who hear, observe, encounter and follow Jesus'. The
Book of Ruth invites readers and hearers to see crises from the points of view of Book of Ruth invites read
Naomi, Ruth and Boaz.

10.Westermann (1999:301), in commenting on the narrative skill in which the two main characters, Naomi and Ruth, are presented, writes that the interplay of these two very different women is presented in high artistry - the wisdom of the older woman and the self-conscious daring of the younger, how they get along with one another and how both co-operate to turn events around'.

11.These are all elements of the plot, the sequence of events in a narrated story (Greenblatt 2006:A66).

12.Siquans (2009:452) points out that ' $\ldots$ although the book of Ruth never mentions poverty, it is a fact that Naomi and Ruth are poor'.

13.This article argues that this sentence is a major theme, a motivating force, in the Book of Ruth (see Lostracco \& Wilkerson 1998:1).

14.Linafelt (2010:117-118) observes what he calls the book's 'reticence in describing its characters; nonetheless, readers and hearers often assume that Boaz is old (although we are never told that) and likewise assume that Ruth is beautiful. Characterisation instead comes via the word hayil; from this word readers and hearers know that Boaz is prosperous and possibly a valiant warrior and that Ruth displays a nobility of character (Rt 2:1, 3:11).

15.Sutskover (2010:283) writes that the son's name, Obed, connotes the concept of 'tiller of the land'; generally, his name is translated 'servant'. Sutskover links the themes of fertility and barrenness in the Book of Ruth. She (Sutskover 2010:285) notes the use of textual elements of famine, the harvests and the setting of Bethlehem (literally House of Bread) in the story.

16. Roop (2002:17) points out that behind what appears at first glance to be an idyllic setting 'of kind villagers, charming landowners, and harvest festivals, readers find a real world, one less than ideal'. Ruth, Naomi, and Boaz are much deeper than heroic foreigner, bitter widow and benevolent landowner. 'The pain is real for naomi, a mother whose world has been turned from pleasant to bitter (1:20). The Naomi, a mother whose world has been turned from pleasant to bitter $(1: 20)$. The
anxiety is intense for Boaz, a pillar of society startled from sleep by a woman at his side $(3: 8)^{\prime}$, Roop (2002:17) writes. 


\section{Historical setting}

The biblical text introduces Ruth within the context of a family crisis (see Block 1999:600-601). ${ }^{18}$ Readers and hearers meet Ruth and two other women at probably the lowest point in their lives (see Loader 1994:32; Eagleton 1991:77). ${ }^{19}$ Ruth has lost her husband Mahlon (see Sasson 1995:18); ${ }^{20}$ her sisterin-law Orpah has lost her husband Kilion; and their motherin-law Naomi has lost not only her two sons but also her husband Elimelech (Rt 1:1-5) (see Fewell \& Gunn 1988:99102)..$^{21}$ The women are not only widows but also are childless, specifically, without sons (see Loader 1994:26-27). ${ }^{22}$ They lack both current protection and future protection. Ruth and Orpah are Moabite women. Naomi and her family emigrated from Bethlehem years earlier because of a famine; they are Israelites (1:1-5). In what must be the first encouraging news in months or years, Naomi hears 'that the Lord had come to the aid of his people by providing food for them' (1:6). Naomi decides to go home, and so the story begins, concentrating on Ruth and Naomi (see Bull 1972:40, 45). ${ }^{23}$ The story's action takes place primarily within six to eight weeks, during

17.See Dillard and Longman (1994:130). The Book of Ruth sets itself in the days in which the judges ruled' (Rt 1:1). This is a time of conflict between the Israelites and the Canaanites (Jdg 4-5) and the Philistines (Jdg 14-16) and others (such as Eglon of Moab, Jdg 1). It would seem, however, that the action in the Book of Ruth occurs in a time of peace between Israel and Moab. The story takes place in the Iron Age. Broadly speaking, the Iron Age in the Ancient Near East was approximately $1300-600$ BC. Ruth and Naomi lived in a time in the history of Canaan, Israel of subsistence farming. In an environment of limited water and limited, usable land survival consisted of, amongst other things, good harvests, reliance on the rains and protection from enemy invaders (see Davis 2009:107-108). Fontaine (2008:22) points out that the foundation of a patriarchal culture is an 'economic ideology in points out that the foundation of a patriarchal culture is an economic ideology in disposition of them'. Recent scholarship, however, suggests a postexilic date for authorship (Dillard \& Longman 1994:130).

18.Whilst the context may be a family crisis, the Book of Ruth carries on an important theme set out in Genesis: how women face a crisis and reverse the crisis for their own good (see Block 1999:600-601). Often a reversal of fortune and a trickster approach are involved. For example, Tamar's crisis was childlessness, and she solved it by tricking her father-in-law Judah to think she was a prostitute (Gn 38 ). Rachel stole her father's household gods and tricked Laban in his search by saying she couldn't rise in his presence because of her period $(\mathrm{Gn} 31: 19,35)$. The tragedies in Ruth's and Naomi's lives invite an active and interactive reading process on the part of the reader (Hansbury 1986:5, 6). However, in the act of reading, one does remain in the world intended by the author (Eco 1984:62). In terms of scripture, one must abide within its literary boundaries in order to find the meaning of a text.

19.Although the narrator never outrightly describes the feelings of the characters in the Book of Ruth, we as readers and hearers can infer them from their circumstances and actions (see Loader 1994:32 for more on this insight). Grief, fear, sadness, anger, bitterness, hopelessness are amongst the normal kaleidoscope of sadness, anger, bitterness, hopelessness are amongst the normal kaleidoscope of (1991:77) writes that 'our initial speculations generate a frame of reference within (1991:77) writes that 'our initial speculat
which to interpret what comes next'.

20.Although some contemporary scholars regard an etymological explanation of a name with disfavour, Sasson does not. He (Sasson 1995:18) points out that the name Mahlon can relate to the root 'to be sterile' or to another root 'to be weak'. In short, his name describes some of his physical conditions, and may indicate why he died young. Childlessness emphasises Naomi and Ruth's dilemma. Bereft of a man's protection, energy and strength, the widows must support themselves and must work to eat.

21.Does the short story present Naomi sympathetically? Fewell and Gunn say no. They (1988:99-102) see her as selfish and cite her silences as supporting this view. Consider these four points:

1. Naomi offers no reply to Ruth's stunning declaration of loyalty (Rt 1:16-17).

2. When Naomi and Ruth arrive in Bethlehem, Naomi ignores Ruth, treating her as if she were invisible (Rt 1:19-22).

3. In Chapter 2, Naomi seems to wait for a man to act rather than taking initiative for herself and Ruth.

4. Naomi gives no comment on Ruth's marriage. She must be chided and reminded by her neighbours that Ruth, her

5. daughter-in-law, loves her and is better to her than seven sons (Rt 4:15).

22. In this sense, Ruth's introduction in the biblical text harkens back to the childlessness of earlier women in the Hebrew scriptures: Sarai (Gn 11:30) and Rachel (Gn 29:31) (see Loader (1994:26-27) for more discussion on this).

23.The story opens with a formula alerting astute, original hearers and later readers that no matter what transpires, the story will end happily. Ruth 1:1, Genesis $14: 1$, Esther 1:1, Isaiah $7: 1$ and Jeremiah 1:3 alike can be translated, 'Now it came to pass...'. Each time the three Hebrew words appear indicates a season of severe adversity but one accompanied by divine deliverance and a happy outcome (see Bull 1972:40, 45) the time of the wheat and barley harvests (see Greenblatt 2006:A66). ${ }^{24}$ Significantly, the narrator presents Naomi and Ruth favourably, conveying in his tone and point of view that he wants them to succeed (see Lostracco \& Wilkerson 1998:26-28; Van Dyk \& Van Dyk 2002:216). ${ }^{25}$

\section{Contemporary features}

The Book of Ruth and Ruth herself provide valuable insights not only for coping in the ancient world but also for coping in today's world in which chaos frequently predominates and losses of home, life, and job strike seemingly at random (see Bland 1981:134). ${ }^{26}$ Although the text and Ruth herself do not say this, Ruth makes creative use of a crisis. ${ }^{27}$ Actually, she faces multiple crises decisively (see Jordaan 2006:9; Sasson $1995: 27) \cdot{ }^{28}$

This article looks at the insights provided by Ruth about facing personal upheaval in the ancient world with courage, ingenuity, perseverance, flexibility and boldness, as well as with a flirtatious femininity (see Lostracco \& Wilkerson 1998:12, 14)!29 This article acknowledges the Book of Ruth's literary artistry (see Roop 2002:16). ${ }^{30}$ It takes a literary approach by emphasising character, plot, setting, tone, dialogue, narration, conflict and resolution (see Lostracco \& Wilkerson 1998). The biblical text is terse, complex and, therefore, fascinating (see Linafelt 2010:120). ${ }^{31}$ The Book of Ruth and Ruth herself offer multiple guidelines for facing multiple crises, especially the crisis of finding food and work (see Propp 1968:25; Baylis 2004:413). ${ }^{32}$

24.The Book of Ruth contains unity, a literary term recognising a consistency of time, place, and action (Greenblatt 2006:A66).

25.The Book of Ruth presents what is called a dramatic or object point of view; the text records only the characters' words and actions (Lostracco \& Wilkerson 1998:26). Other points of view that the Book of Ruth (and the biblical text as a whole) avoids are first person narration, complete omniscience and limited omniscience (see Lostracco \& Wilkerson 1998:26-28).

26.These losses are loosely called evil in the biblical text. Various explanations are offered for evil. Bland (1981:134) mentions three:

1. A person can choose between right and wrong.

2. Suffering can be a way God shakes a person or a community out of selfsufficiency (Am 4:6-13).

3. Suffering contributes to training and educating God's people.

27.This phrase Do not let a good crisis go to waste!, is not my own but was the mantra of Rahm Emanuel, the former chief of staff of US Pres. Barack Obama. See the excellent article 'Victory claimed in the 100 days war, but tougher battles lie ahead' by D. McManus (2009). The phrase also has been repeated regarding the debt / default crisis faced in July 2011 by the US.

28.Jordaan (2006:9) follows a trend in modern scholarship by noting that the dominant story is that of Naomi and not that of Ruth. Naomi's story, however, whilst going beyond the scope of this article, certainly merits more scrutiny. Clearly an aspect of Naomi's pilgrimage is her journey from bitterness to contentment, from emptiness to fullness, and from feeling that God has a personal vendetta against her to seeing that God has provided her a son. Indeed, Sasson (1995:27) uses this strong word, vendetta, in describing Naomi's assessment of God's dealings with her.

29.Ruth is a round, dynamic character. She shows multiple sides of her personality her silences add to her complexity (Lostracco \& Wilkerson 1998:12, 14).

30.J.W. von Goethe (1749-1832) characterised the Book of Ruth as one the most beautiful short stories in all literature (Roop 2002:16).

31.Linafelt (2010:120), commenting on characterisation, writes that '... by not revealing the qualities of character of the actors in the narrative, the narrator puts the onus of interpretation on the readers, who must work out on their own - albeit with hints given - what they think of these characters. This is not the absence of characterization, but is a certain mode of characterization and, in fact, a fairly complex mode at that.'

32.Propp (1968:25) notes that a story begins with an initial situation like the multiple crises Naomi and Ruth face. Baylis (2004:413) observes that the story lacks a physical villain; however, villains can take non-human form in the sense of famine, death and economic hardship. 


\section{Ruth converts to Israel's God and chooses to accompany Naomi}

Do not let a good crisis go to waste! Ruth's actions and her three brief speeches (see Block 1999:588) ${ }^{33}$ show that she uses the crises at hand - bereavement, destitution, barrenness, and survival (see Propp 1968:30; Lostracco \& Wilkerson 1998:21) $)^{34}$ - to make wise decisions. It is the author's opinion that readers and hearers today can relate to Ruth's struggles and triumphs. Ruth is proactive and not placid in her struggle to provide for herself and her mother-inlaw. In the process, not only does her character shine, but it also deepens; she is not a static character but a developing one too (see Lostracco \& Wilkerson 1998:14). Although the word hope is not mentioned, Ruth's actions express hope (see Scioli, Ricci, Nyugen \& Scioli 2011:94). ${ }^{35}$ Nevertheless, the extraordinary suffering of Ruth and her mother-in-law, Naomi, brought on by these crises cannot be dismissed or glossed over (see Van Dyk \& Van Dyk 2002:2009-2024; Propp 1968:39). ${ }^{36}$ Their losses bring them prolonged agony; indeed, the text records Naomi's bitterness and anger (1:13, 20-21) (see Mancini, Bonanno \& Clark 2011:144; Exline, Park, Smyth \& Carey 2011:138). ${ }^{37}$

The Book of Ruth ends with the women surviving and even flourishing. Yet, their initial calamities heralded an irrevocable disruption - economic, social, psychological and spiritual - in their lives. Ruth leads the duo as they begin a new season that involves both recovery and survival. However, when looking at Ruth's decisions and her journey, it is important not to minimise the suffering she faced in virtually every area of her life (see Roop 2002:22)..$^{38}$

Ruth begins her new life with conversion. She chooses to follow the God of Israel. In perhaps the book's most beloved verse, Ruth tells Naomi, 'Don't urge me to leave you or to

33. Because Ruth gives only three short speeches, much of modern scholarship finds it remarkable that the book carries her name. Perhaps the text should be called the Book of Naomi, because Naomi is the central character and Ruth is from Moab and outside the covenant (see Block 1999:588).

34.Naomi and Ruth's crises - bereavement, destitution, barrenness, and survival serve as enemies in the story. Propp (1968:30) notes that a villain causes harm or injury to a victim. The crises certainly provide a conflict Naomi and Ruth must overcome (Lostracco \& Wilkerson 1998:21).

35.Scioli et al. (2011:94) agree that hope can be likened to a 'healthy portable environment.'. In other words, Ruth's earlier character traits come to the fore in facing her present crisis, and one of those traits is hope.

36.See Van Dyk and Van Dyk (2002). Propp (1968:39) notes that a story involves the testing of the hero. Ruth certainly faces tests.

37.Modern psychological theory has long noted that people react to major events in life like bereavement and joblessness but then eventually return to their normal state of well-being (Mancini et al. 2011:144). Ruth seems to be an example of that state of well-being (Mancini et al. 2011:144). Ruth seems to be an example of that
general tendency. However, Naomi's bitterness shows the response pattern of another individual (see Mancini et al. 2011:144). Warning against characterising life's events in generalities, Mancini et al. (2011:151) write that 'the impact of life events may depend largely on individual differences and on life circumstances'. Another modern study indicates that 'participants interpreted the term negative feelings toward God as implying anger rather than sadness, fear, or guilt' (Exline et al. 2011:138). Naomi's words (Rt 1:8-13, 20-21), whatever their tone, indicate a deep-seated anger and a daily mental rehearsal of it. This same study found that younger people who lost a loved one were more likely 'to hold God responsible for the loss' (Exline et al. 2011:140). In contrast, Naomi is an older widow and yet still holds God responsible for the loss of her husband and sons.

38. Ruth and Naomi act not in response to a divine command but to the losses they experience; there is no dramatic, divine intervention. Chapter 1 introduces the family in terms of famine and death (see Roop 2002:22). As the story progresses, the women seek to activate the existing societal structures (gleaning and marriage) for their benefit (Roop 2002:75). turn back from you. Where you go I will go, and where you stay I will stay. Your people will be my people and your God my God' (1:16) ('Ruth, Book of' 1971; Sasson 1995:30). ${ }^{39}$ Ruth's declaration calls on God to keep his covenant. Ruth makes a decision and God blesses it radically (see Baylis 2004:427). ${ }^{40}$

The radical nature of this decision cannot be over emphasised (see Burnett-Bletsch 2007:248; Bull 1972:45). ${ }^{41}$ Ruth leaves her home, country and gods. Significantly, she stops any search for a husband in her own land in order to provide economically for her mother-in-law in Naomi's land (see Greenblatt 2006:A73). ${ }^{42}$ She binds herself to a cranky, elderly woman who describes herself as past childbearing age and bitter (Rt 1:11, 20) (see Baddeley \& Singer 2009:202)..$^{43}$ Naomi gives no indication in the text that she is able to work; indeed, once she arrives in Bethlehem, she stays home (Rt 2:2,18). ${ }^{44}$ Arguably, Ruth saves Naomi's life (see Propp 1968:43). ${ }^{45}$

Ruth chooses to immigrate to Bethlehem (see Propp 1968:39). ${ }^{46}$ Acting in a non-traditional way, Ruth does not look for a man to protect them. Neither does she wait for one to show up. Instead, she looks to herself to protect an old woman embittered by losses and angry at God (see Sasson 1995:27). ${ }^{47}$ Trible (1978:173) is correct when she boldly declares: 'Consequently, not even Abraham's legacy of faith surpasses this decision of Ruth.'

Ruth's conversion forms the foundation of the story. The Book of Ruth shows that God hears her words, takes them seriously, works behind the scenes on her behalf (even in what seems the worst of times) and accomplishes His plan. Amazingly, Ruth's life blesses generations. The plot's details include the famine, marriages and deaths; the journey to Bethlehem; the hard work of gleaning; the courage of

39.Traditional rabbinic comment on the phrase, 'your people will be my people' is that Ruth vows to destroy all idolatry within her ('Ruth, Book of' 1971). Sasson (1995:30) notes that in Ruth's choice of lun, to lodge, the narrator may be implying 'that Ruth was willing to share with Naomi any unsettled future, so long as nothing parted them'.

40.Examining the verb shub, to return, which occurs frequently in Chapter 1, Baylis (2004:427) notes the possible difference in perspective between Naomi and Ruth 'While Naomi believed that the value of the return was to be found in physical prosperity, Ruth realised that her return gave her the privilege of a relationship to prosperity, Ruth realised that her return gave her the privilege of a
the God whom she had come to love', Baylis (2004:427) maintains.

41.Throughout the biblical text, the broad principle of retribution theology (the idea that obedience brings blessing and disobedience brings punishment) prevails. yet the biblical text also shows instances where repentance from disobedience reverses a crisis or disaster. Burnett-Bletsch (2007:248) sees the portrayal of Manasseh in Chronicles this way. Likewise, perhaps Elimelech's decision to leave Bethlehem, the house of bread, for Moab led to death (Rt 1:1-3). Certainly the biblical text renders no indication that he prayed about his decision, sought the Lord, or was told by the Lord to leave Bethlohem (see Bull 1972:45). Consequently, hord, or was told by the Lord to leave Bethlehem (see Bull 1972:45). Consequently, Her decision clearly reverses the bad tide of the family fortunes.

42. Most of the action takes place in Bethlehem; in literary terms, Bethlehem is the 'scene' (Greenblatt 2006:A73).

43.Naomi evidently tells and retells the story of her losses. Modern research on bereavement indicates that 'disclosing the narrative of one's loss does not per se promote emotional recovery' (Baddeley \& Singer 2009:202).

44.Perhaps the text contains some irony here for Naomi at least had the strength to walk from Moab to Bethlehem.

45.A key element of a story is that a hero performs some service (Propp 1968:43), usually it is extraordinary. Ruth consistently performs extraordinary service. She leaves Moab; she gleans; she proposes marriage to a man capable of providing for her and her mother-in-law.

46.Propp (1968:39) puts it this way: The hero leaves home.

47.Naomi thinks that God has been especially unkind to her, even so unkind as to be enacting a private vendetta against her (Sasson 1995:27). 
going to the threshing floor for an assignation at night; the boldness of a Moabite proselyte proposing to a prominent, unmarried Israelite and the white-knuckle, winner-take-all meeting at the city gate. All these details come within the narrative's focus on Ruth's conversion. The Book of Ruth gives encouragement that God's plan is good.

\section{Survival insights gleaned from the Book of Ruth}

After Ruth's declaration, in which she switches her allegiance to the God of Israel, her life takes on an adventurous quality. In her struggle to survive and to provide for her mother-in-law and herself, (see Nairne, Thompson \& Pandeirada 2007:271) ${ }^{48}$ Ruth encounters unexpected kindness from the foreman, the gleaning girls and the owner of the field himself, Boaz (Rt 2) (see Siquans 2009:452). ${ }^{49} \mathrm{He}$ commands his field hands not to touch her and to make sure she receives ample gleanings (2:9, 15-16). When Boaz calls Ruth 'my daughter,' (Rt 2:8-9) he publicly displays a kindness to her befitting his seniority in age and social status (see Loader 1994:28). Textual surprises like this are a narrative tool.

In an adventure, expect to meet people of like character and disposition along the way. Ruth does when she meets Boaz. Each is described as a hayil, a person of character $(2: 1 ; 3: 11)$. The women of Bethlehem become her friends and admirers (4:14-17). According to rabbinic tradition, the Book of Ruth emphasises the community's treatment of outsiders (see Sakenfeld 1999:4). The people of Bethlehem end up treating Ruth well.

Furthermore, the story of Ruth points to God's control over one's steps. Bush (1996) puts it as follows:

Not only Boaz's faithfulness and Naomi's risky plan are part of God's controlling, behind-the-scenes hand, but also Ruth's steps are shown as God's interest in the world he has created. (p. 47)

Certainly, in the case of the prayer and blessing of Boaz, this is true (see Sasson 1995:51; Bland 1981:131). ${ }^{50}$ Ruth comes under his wing $(2: 12 ; 3: 9)$.

In an adventure, expect not only unexpected kindnesses, but also detours. In literary terminology, they are called surprises. For example, it is expected that a man provide for his family. But in the Book of Ruth, Ruth provides for Naomi. Perhaps that kind of sacrifice by a woman for another woman is so rare that it causes wonderment by Naomi's friends. They express it this way: Ruth, the daughter-in-law, is better to and for Naomi than her seven sons (4:15).

48.A modern study argues that memory systems 'evolved to help us solve problems, particularly problems related to survival' (Nairne et al. 2007:271). The Book of Ruth shows that Ruth was creative and intuitive about solving her problem of survival.

49.Siquans (2009:452) argues that the Book of Ruth shows that Ruth attains a legal status that allows her to marry because she is wife of a dead Israelite (Rt 4:5, 10). Siquans (2009:450) also notes that Ruth has legal rights to look for food based on Deuteronomy 24:19, a verse which allows the alien, the fatherless and the widow the right to glean.

50.Sasson (1995:51) also noticed this as a result of Boaz's prayer. Boaz prays, 'May the Lord repay you for what you have done. May you be richly rewarded by the Lord, the God of Israel, under whose wings you have come to take refuge' (Rt 2:12). Bland (1981:131) explains that 'blessing does not always refer to the actual advantages which are granted by it. But when a blessing is given, it is the potential advantages which are granted by it. But when a blessing is given, it is the potential
power that is transmitted.' Certainly in the case of the prayer and blessing of Boaz this is true.
In another significant plot twist, Ruth just happens to look for sustainable work and finds it in the field of Boaz, a man in Elimelech's family positioned to be a kinsman-redeemer (2:1-7, 20). The writer's tone, which reveals his attitude toward his subject (see Lostracco \& Wilkerson 1998:49), seems to indicate that the Hebrew phrase wayyiquer miqreha (2:3) be read with a smile. This phrase could be translated in the following ways: 'It just so happened'; 'Her encounter encounters' (see Block 1999:609); 'Her hap happens'; 'As chance would have it'; 'Her luck brought her to'; and 'As it turned out'. It even carries an overtone of an exclamation: 'And can you imagine! ${ }^{51}$

\section{Aspects of Ruth's character in an ongoing crisis and God's guidance}

In a crisis, extend kindness to others. The Bible calls loving kindness 'hesed'. ${ }^{2}$ Naomi introduces this theme when she says to Orpah and Ruth, 'May the Lord show kindness [hesed] to you as you have shown to the dead and to me' (1:8). The concept of hesed generally means that someone of higher rank extends kindness to someone of lesser rank. Often without immediate hesed, the supplicant faces death. The Book of Ruth significantly expands the concept that somebody prays for somebody else $(1: 8-9 ; 2: 20 ; 4: 11-12,14-15)$ (see Block 1999:612-613). Truly, there is a correspondence in the Book of Ruth between how people act toward each other and how God acts toward them (see Campbell 1985:29).

Ruth not only extends kindness but also keeps on extending kindness. Hesed marks her character. The ways in which Ruth extends kindness are to travel with Naomi to Bethlehem, to work to support Naomi and herself in the fields of barley and wheat and to propose marriage to Boaz (1:22; 2:2ff; 3:9-10). The consequences of Ruth's actions of repeatedly extending kindness are that a son named Obed is born and a good life (with provision and hope for a future) replaces Naomi's earlier feelings of bitterness and emptiness (see Bush 1996:11-12). ${ }^{53}$

Ruth certainly engages in hard physical labour. The text emphasises this, perhaps to the wonderment of the people in Bethlehem. Evidently the Moabites did not have a good reputation on several levels with the Israelites. Firstly, the Moabites descended from an incestuous union (Gn 19:30-38). Secondly, Jeremiah 48:11 sketches an unfavourable character portrait of the Moabites. He writes, 'Moab has been at rest from youth, like wine left on its dregs' see Bull (1972:57, $60)$. Consequently, in contrast to most of her countrymen, Ruth, a self-starter, exhibits energy and initiative. Negative assessments of Israel and her neighbours in the biblical text are not uncommon..$^{54}$

51.The latter is my own translation and reflects what I hear as the narrator's tone.

52. Hesed is mentioned in Ruth 1:8; 2:20 and 3:10.

53.Bush (1996:11-12) calls it a resolution of death and emptiness.

54.Jerusalem, for example, also was not exempt from a harsh prophetic word against laziness. Consider Zephaniah 1:12: 'At that time I will search Jerusalem with lamps and punish those who are complacent, who are like wine left on its dregs, who think, "The Lord will do nothing".' Also consider the prophetic regional indictments think, "The Lord will do nothing". Also consider the prophetic regional indictments
against Damascus, Gaza, Edom, Ammon, Moab and even Judah and Israel (Am against Damascus, 
Ruth seeks work with immediate payment. In accepting a menial position, she faces hard economic facts: she needs immediate work in order to eat. Significantly, the text remains silent about any help the townspeople might have given the returning Naomi and her Moabite daughter-in-law (Rt 1:19-22). Considering that none is mentioned, most probably none was offered. Ruth becomes Naomi's unexpected helper. Significantly, the text mentions nothing about Ruth's concerns or her desire to be back in Moab. By working at the lowest job in town, Ruth demonstrates that she was not concerned about her image (see Hess 1979:47). She exhibits no second thoughts, no modern 'buyer's remorse' about her decision to come to Bethlehem. Ruth does not look back.

Significantly, Ruth finishes what she starts. Gleaning and any farm work are hard, hot, heavy physical labour. I once was asked if I had ever picked cotton. 'No,' I said. 'Then you really haven't lived,' came the reply. Perhaps the same is true of gleaning. Granted, Ruth cannot abandon her work although it is very demanding physically for she is the sole provider for herself and her mother-in-law. The text points out that Ruth not only gleaned until evening, but also threshed the barley (2:17). In other words, she completed the entire task of finding food and preparing it to be used. Her work earned her about an ephah, approximately 22 litres or three-fifths of a bushel (Sasson 1995:57; Propp 1968:45)..$^{55}$

\section{A crisis can entail silence}

Ruth adapts well to her new life in Bethlehem. She does not try to change the conditions she encounters. It seems that Ruth had determined beforehand that she was the one who would need to change. After all, she had left her family, culture, and gods for the family, culture and God of Naomi. She chooses a new life.

When reading a biblical story, a helpful analytical tool entails imagining what a character could have done or said in a situation. For instance, Ruth could have arrived in Bethlehem and told the people how much better things were in Moab, laughed at them for their backward farming methods, and pointed out that the earlier Canaanites had manufactured more metal tools and weapons than did the Israelites. ${ }^{56}$ But she does not. Ruth's natural reticence and her silences add to her mystery. They make her more prominent. They give her grace. When she speaks, she speaks wisely. Her words are well chosen, forceful and memorable.

In the same vein, Ruth keeps many opinions to herself. Textual silences are clearly a narrative tool. The text reports no corrective response to Naomi against God (1:11-13, 20-21). Ruth tactfully refrains from correcting Naomi's theology or opinions. The narrator lets stand Naomi's words; the narrator reveals nothing of Ruth's thoughts. The Moabite woman

55.Sasson (1995:57) thinks it is possible she gathered anywhere from 29 to 55 pounds of grain, enough for herself and her mother-in-law for about two weeks. Often food or drink becomes an important element in a story and is consumed by the hero (Propp 1968:45).

56.The Canaanites certainly had modern warfare tools. Judges 4:3 states the Canaanites under Sisera had 900 chariots, the ancient equivalent of weapons of mass destruction. The text remains silent on any counterbalancing weapons on Israel's side. offers no comment on Naomi's theology that the hand of the Lord is stretched out against her (Rt 1:13, 22). Indeed, throughout the biblical text and now in the Book of Ruth, the opposite theological view prevails: God's strong right arm extends in mercy and power toward his covenant people when they seek him and are obedient to his commands (see Roop 2002:17).

\section{People observe a person undergoing a crisis}

Ruth accepts the fact that she is talked about as a new person and as a Moabitess. Everything about her as 'the new girl in town' receives scrutiny. Yet her behaviour gives the townspeople no opportunity for gossip. And they probably looked for a chance to do just this!

Ruth's conduct, however, remains exemplary (see Kim \& Grant 1997:243). ${ }^{57}$ Notice how Boaz, the story's hero, praises her in front of everybody - his workers, foreman and the other gleaners. He says, 'I've been told all about what you have done for your mother-in-law since the death of your husband, how you left your father and mother and your homeland and came to live with a people you did not know before' (Rt 2:11).

Ruth responds by showing her humorous and even flirtatious side. When Boaz publicly prays for her to receive a reward from God, Ruth publicly replies with her own hope that she may continue to find favour in the eyes of Boaz (Rt 2:12b-13a). She flirts a little with him by calling him my lord and by thanking him publicly for speaking kindly to her, even though his servant girls have more standing in the community than she. She speaks well of him in front of his workers. ${ }^{58}$ Those listening probably smiled. Ruth is a very wise worker!

Ruth acts in a chaste manner (see Schwartz, Weisskirch, Zamboanga, Ham et al., 2011:27). ${ }^{59}$ The Hebrew Bible (Old Testament) presents sexual matters forthrightly ${ }^{60}$ and duly notes her lack of sexual promiscuity. Where does she sleep? Chapter 2 ends with this answer, 'And she lived with her mother-in-law' (Rt 2:23). Boaz evidently also had noticed her living arrangements, for he again commends her, but this time privately when they are alone at night on the threshing floor. He says, 'You have not run after the younger men, whether rich or poor' (Rt 3:10b).

57.A modern study of immigrant and Korean American women finds they are a population 'at risk for substance abuse, suicide, battering, loss of employment, deficits in parenting, and mental health problems' (Kim \& Grant 1997:243). Ruth's profile, as seen in the biblical text, gives no evidence of any of these patterns.

58. Abigail also flirts with David openly in front of his men, calling him my lord (a designation that can mean husband!), reminding him of his life with the Lord, and telling him she believes he will have a lasting dynasty (1 Sam 25:23-31). In short, Abigail is the first in the biblical text, in addition to the prophet Samuel, to affirm David's anointing as Israel's future king. Quite possibly Jonathan, Saul's son, knew it, too (see 1 Sam 20:12-14).

59.Studies show that behaviour patterns (called heritage practices) before immigration are carried on after immigration (Schwartz et al. 2011:27). Ruth showed no evidence of promiscuity.

60.See Genesis 19:30-38; 38, 39; Judges 19, Ruth 4:13; 2 Samuel 11, 13, 16:21-22, etc. Also notice Ruth 4:13: 'So Boaz took Ruth and she became a wife to him, and he went into her and Yahweh gave to her conception and she bore a son.' 
The narrative pauses for an extended look at the threshing floor scene. Sakenfeld (2002:166) says that chapter 3 is 'fraught with the possibility of sexual intercourse'. Words and phrases with double meanings include feet (traditionally a euphemism for genitals) $(3: 7,8,14)$; to lie down, used eight times in verses $4-14$; to uncover $(3: 6,7)$; and to go into $(3: 4,7,14)$.

Did sexual intercourse take place (see Baylis 2004:428-430)? ${ }^{61}$ I do not believe that it did; others believe it did (see O'Kane 2010:144-143).62 I side with Ruth's chastity and Boaz's restraint. (see Ostriker 2002:356) ${ }^{63}$ The reason I say this is because there is ample textual evidence already given for their celibacy. The narrator presents each as a person of noble character (Rt 2:1; 3:11; see Block 1999:690, 692) ${ }^{64}$ Although I believe there was plenty of natural attraction, I do not think consummation occurred. However, I think Boaz was terribly flattered that he was pursued in such a way. The tone of the text is favourable toward Ruth and Boaz (see Lostracco \& Wilkerson 1998:49). ${ }^{65}$ Consequently, the text invites us as readers and hearers to smile with understanding about what is happening. It invites us to imagine the scene. It creates suspense by leaving its readers and hearers wondering whether these two exemplary people will marry and find joy with each other, and hoping that they will!

My imagination (see Iser 1984:52) ${ }^{66}$ as a woman marks the scene as the most memorable conversation of Ruth's life and of Boaz's life, one each would remember with fondness. What did they talk about? Quite likely they grew to know

61.Baylis (2004:428-430) believes that Naomi, in sending Ruth to meet Boaz at night at the threshing floor, goes against the Mosaic Covenant in four ways. These include the following:

. Naomi should have referred to Boaz as the legal next of kin or redeemer (a legal term), instead of as a kindred, a non-legal term similar to the word kin.

2. Naomi should have sent Ruth to the city gate during the day, the normal place and time for legal matters.

3. Naomi should not have insisted that Ruth change from her mourning clothes, clothes which identified her legal and societal status.

4. The matter of the legal obligation of Boaz should have been brought up not when he was influenced by food, drink and exhaustion from the harvest.

In contrast to Naomi, Boaz responds in a manner in accord with the Mosaic Covenant; he promises Ruth that she will be taken care of by him or by another kinsman redeemer (Baylis 2004:430).

62.Others, however, emphatically say yes. One is the painter Marc Chagall who did a series of paintings on the Book of Ruth. O' Kane (2010:144-143) in writing about two of them, Ruth at the Feet of Boaz and Boaz Awakes and Sees Ruth at his Feet, says the mood conveyed is sensual and sexual. O' Kane (2010:143) describes the two paintings this way: 'As Ruth lies at the feet of Boaz, her breasts reflect the light of the shimmering moon, whilst in the final picture, both figures are naked. The throbbing red sun suggests the passion of their union, whilst the sheaves of wheat suggest the fruitfulness of their future marriage. The reclining position of the fully clothed Boaz with his arm above his head as he sleeps in the penultimate image is reversed in the final image as the naked Ruth with her arm above her head reclines in rest. Unlike the biblical text, which is ambiguous as to what took place on the threshing floor, Chagall's interpretation leaves nothing to the imagination.'

63.Ostriker (2002:356) also sides with the chastity of Ruth and Boaz. She writes that '... what charms us in Ruth is the inextricability of ethical behavior from erotic gratification'. Is Boaz doing the right thing, and more than the right thing, is gratification'. Is Boaz doing the right thing, and more than the right thing, is he acting as God wishes men of honour to act, because he is attracted to this
attractive woman? Well, yes. And is he attracted to her in part because she herself attractive woman? Well, yes. And is he attracted to her in part because she herself join as, and at the moment of, harvest.'

64.Block $(1999: 690,692)$ argues that Boaz does not interpret Ruth's unexpected presence as an offer of sexual favours; furthermore, 'instead of cursing her and shooing her off as some immoral whore, he blesses her.' Block's insights back up my view that Boaz and Ruth did not commit fornication.

65.A story's tone reveals the author's attitude toward the characters or subject matter (Lostracco \& Wilkerson 1998:49). An indication of the author's favourable tone is the long recorded conversation amongst Naomi, Orpah and Ruth $(1: 8-18)$. The conversation expresses values of sacrifice, love, devotion and faith.

66.Iser (1984:52) writes that a reader's imagination sets a given situation against a background which endows it with far greater significance than it might have seemed to possess on its own. each other. After all, the text up to this point records only their initial meeting and no further conversation between them during the harvests. Perhaps alone at night on the threshing floor they talked about their pasts, their hopes for the future, the people in their lives, their losses, silly things, deep things, in short anything that came to mind! Quite likely there was quiet laughter. What did they do? Most probably Boaz embraced her (see Lucas 2003:180-184). ${ }^{67}$

Before daylight, Ruth returns to Naomi with six measures of barley, a gift probably laden with symbolism. ${ }^{68}$ The lavish gift possibly indicates a commitment to ongoing provision. Naomi asks, 'How did it go, my daughter?' (Rt 3:16). As one says in English, this is a loaded question! It probably means a jumble of the following emotions and questions: 'Did you succeed? Were you molested? Did you have sexual intercourse? I've been praying for you throughout the night! Tell me everything'!

And Ruth tells Naomi everything, gives her the six measures of barley as a gift from Boaz and recounts what he said, 'Don't go back to your mother-in-law empty handed' (Rt 3:17). One can picture the elderly matchmaker nodding and smiling as she listens.

From Ruth's words, the narrative indicates that Naomi knows Boaz wants Ruth, and his desire for her is so strong that he will act quickly. Notice that Naomi does not refer to him by name but says 'the man will not rest until the matter is settled today' (Rt 3:18). Perhaps she and Ruth exchange excited hugs.

\section{People in the workplace watch newcomers}

Ruth's behaviour remains constant. In a crisis, expect character traits to be magnified. Ruth shows no negative character traits (see Block 1999:613-614). ${ }^{69}$ Instead, her behaviour remains consistently outstanding. The book chronicles her story from the time of her husband's death in Moab, through both the barley and wheat harvests in Israel, and on to her marriage to Boaz and the birth of their son. The harvests occur within weeks of each other (see Sasson 1995:38).$^{70}$ The story portrays Ruth's perseverance, faithfulness, ingenuity, graciousness, tenacity, courage and boldness. She works as a gleaner, society's lowest job, but works hard with dignity and without complaint.

Sometimes it's helpful to imagine alternative paths a person could have chosen and to consider what other responses a

67.Love is not a foreign concept in the literature of the ancient Near East. Sumerian and Egyptian texts in particular and Uggaritic texts to a lesser extent exhibit traits similar to the Song of Songs, the Bible's great love poem (Lucas 2003:180-184).

68.The symbolism, however, is lost on modern readers. However, because the biblical text mentions numbers rarely, the times when it specifies a number are generally treated as significant. Six is traditionally the number associated with humanity, because man and woman were created on the sixth day. It seems safe to say that the narrator assumes that readers and hearers will know the meaning of six measures of barley. Naomi surely did.

69.In this, she resembles other exemplary characters in the Hebrew Bible: Joseph, Daniel, and Esther. Boaz himself is called a gibbor hayil (Rt 2:1), a designation connoting honour, prosperity, nobility and sterling character. See Block (1999:613-614) for some good insights on this. Another gibbor hayil is Naaman the Syrian (2 Ki 5).

70.According to the Gezar Calendar, the barley and wheat harvests occurred in April / May and May / June (Sasson 1995:38). 
person may have had to a set of circumstances. Ruth never whines, complains or expresses anger; she refrains from engaging in the poetry of lament. ${ }^{71}$ Ruth could have stayed at home in Moab, a choice Naomi indicates as easier than relocating to Bethlehem (1:11-13). Ruth could have talked in a disrespectful way to Naomi, her elder. Ruth could have been promiscuous.

Instead, Ruth exhibits humility, courtesy, wisely-chosen words and chastity. People remember her gracious words and good manners. Although she is an adult, she asks permission of her mother-in-law to go and glean (2:2). Her good manners likewise are evident in the workplace. ${ }^{72}$ The field foreman recounts to Boaz that she asked permission from him to glean in the field. The text records she even said please, a word used with emphasis elsewhere in the biblical text (see Harris, Archer \& Waltke 1980:2:541). ${ }^{73}$ 'Please let me glean and gather amongst the sheaves behind the harvesters,' Ruth said (2:7). Actually, verbal courtesy and good manners abound in the Book of Ruth and in the workplace, the barley field, itself (see Lostracco \& Wilkerson 1998:35). ${ }^{74}$ Boaz greets his workers with this cheery blessing: 'The Lord be with you'! The workers respond with an equally gracious reply, 'The Lord bless you'! (2:4) (see Ginzberg 1968:6:191). ${ }^{75}$

Ruth honours others. By her hard work, she honours Naomi, who evidently is old and cannot provide for herself anymore. Ruth honours Boaz in front of his field hands. When he singles her out in front of everybody, she listens courteously and then, amazingly, bows face down on the ground and addresses him from the ground by looking up at him (2:10). ${ }^{76}$

Ruth dresses for success. Despite her impoverished economic condition, the text arguably shows she knows she is attractive. Quite likely she dresses modestly yet becomingly, even for work in the field. Something must have singled her out from the other women workers in the field. Boaz's first question (2:5) when he comes to check his field is, 'To whom does that young woman belong?'

The text indicates that Ruth makes an excellent first impression. Boaz likes what he sees (see Harley 1986). ${ }^{77} \mathrm{~A}$ true woman, Ruth enjoys being noticed. She responds in a

71.David composes lament psalms in times of difficulty (see the superscriptions for Ps 3 and 142); Job challenges God (Job 29-31); Ruth writes nothing.

72.Not only do her courteous requests to her mother-in-law and the foreman to glean in a field show her good manners, they also show that she plans ahead. She enters the job market, so to speak, seeking to work in a field belonging to someone 'in whose sight I might find favor' (Rt 2:2).

73.The word $n a^{\prime}$ can mean please, now, or even I pray. It is a particle of entreaty or exhortation and used in Genesis 12:13; Numbers 20:10; Psalm 118:25 (Harris et al. 1980:2:541). An interesting word, na [now or please], is used in Genesis 22:2 'Take, now/please, your son, your only son Isaac, whom you love, and go ...'.

74.Diction refers to the author's choice of words (Lostracco \& Wilkerson 1998:35). The brevity of the biblical text indicates a careful choice of words.

75.An interesting sideline is that courtesy greetings changed in Israel. Rabbinic tradition notes that the salutation, 'The Lord bless you', that was common in the days of Boaz and Ruth was absent during the reign of Athaliah (Ginzberg 1968:6:191).

76.Judith (Jdg 10:23), Abigail (1 Sam 25:23-24), and Esther (Es 8:3) all bow before a man in authority, and all eventually get what they want.

77.Many men appreciate a good-looking wife; see Harley (1986), especially pages 100-102. sweet, flirtatious way that acknowledges his interest, praises him as a man and makes him look good in front of his workers. No doubt her actions and words bring smiles to all in hearing distance. Ruth shows her intelligence, grace and humour. Ruth lets Boaz know she has noticed him too and that she likewise likes what she sees!

The silences in the text bear more scrutiny. ${ }^{78}$ From Ruth's first day of work in Boaz's field to their night-time meeting at the threshing floor, the text records no additional verbal communication between them. It is all right to imagine the daily drama during the harvests, for the text encourages both participation in a story and one's own visual imagination (see Sakenfeld 2002:168). ${ }^{79}$

Let us assume that during the six-to-eight weeks of the barley and wheat harvests Ruth and Boaz made eye contact. Maybe they exchanged nods. Maybe they took a break together at the water jars. Maybe they ate together in public during the communal meals. Undoubtedly they assessed each other during the working season. As the story soon verifies at the threshing floor, each gave the other a positive assessment.

Perhaps likewise the harvest workers noticed the non-verbal cues going back and forth between Boaz and Ruth. Perhaps they enjoyed the development of a romance. Perhaps it created a winsome diversion during a time of hard labour (see Fewell \& Gunn 1989:54). ${ }^{80}$

\section{Waiting on God: Transitions in the Book of Ruth}

Ruth waits. The ability to wait, a sure sign of emotional and spiritual maturity, gives God time to move gloriously on one's behalf. Ruth waits through bereavement, the journey to Bethlehem, the adjustments of life with new people, poverty, and the hard work of the barley and wheat harvests. The text indicates she waits silently. A South African expression about waiting is to carry on. Whilst she waits, Ruth 'carries on' with the tasks at hand, namely, feeding herself and her mother-in-law, making new friends, adjusting to a new life in Bethlehem. Actually, Ruth waits actively.

Ruth gives people space to be themselves. With kindness and humour, the biblical text presents Naomi as a woman with strong opinions, one who quite possibly is hard to live with. Probably Ruth's companionship, having enough to eat and being back home in Bethlehem all work together to soften Naomi. Arguably, God pampers her with rest and food.

78. A significant silence exists between two of the three major characters: Boaz and Naomi. They never meet or speak in the text although they clearly know each other by reputation $(2: 11,20)$. Ruth serves as their go-between.

79.As Sakenfeld (2002:168) correctly observes, readers are always filling in the gaps of a text with their imaginations.

80.Fewell and Gunn (1989:54) see Boaz and Naomi as equally entrapped by the patriarchal system. Boaz, they write with a combination of cynicism and truth, 'wishes to marry the Moabite woman and does so. His profession of commitment to the name of the dead is hollow. He cares no more for Mahlon and Elimelch than does the narrator. They are but weapons in his hand as he defeats one set of prejudices by wielding another. The measure of his faithfulness, then, surely lies somewhere else, somewhere in the offer of grain, and the spreading of a wing, in the exercise of hesed, for mixed reasons, in a compromised world.' Boaz clearly plans ahead regarding the encounter with the unidentified male relative and gets what he wants. 
By Chapter 3, the end of the wheat harvest, Naomi shows some emotional healing from her bereavements; she is able to think past her own needs to Ruth's permanent welfare. Soon feeling like her old self, she makes a plan, as one says in South Africa, and matchmakes her way to security. Naomi decides it is time for Ruth to settle down in a new home of her own (Rt 3:1). Ruth listens to advice; specifically, she heeds Naomi's advice. Naomi, that lovable, meddling matchmaker, has picked Ruth's husband, Boaz. ${ }^{81}$

In addition, Ruth must wash herself, put on perfume, wear her best dress and go to the threshing floor where Boaz is keeping watch (Rt 3:1-4). Does Ruth shed her widow's garments and dress in a way signifying she is ready for marriage (see Walsh \& Shulman 2007:368) ${ }^{82}$ We as readers and hearers don't know. ${ }^{83}$ We do know, however, that Naomi's advice is meant to make Ruth as physically attractive as possible (see Sakenfeld 2002:165; Propp 1968:54) ${ }^{84}$ For an encounter that will change their lives, Ruth obeys Naomi and probably dresses very becomingly!

Significantly, Ruth asserts herself only after earning the respect of others, only after she is confident in her new environment, only after she has made friends. When the scene changes to the threshing floor, gender roles switch. Ruth proposes to Boaz, telling him he needs to marry her because it is his duty, 'Spread the corner of your garment over me, since you are my kinsman redeemer' (Rt 3:9). By her bold request (unique in the biblical text), Ruth gently rebukes yet compliments Boaz. She knows the law, as does he, about the next-of-kin's duty to raise up offspring for the man who has died to preserve his name in Israel. Boaz indicates he has thought about marrying Ruth. It seems that shyness or knowledge of another with a closer blood tie or ethnic prejudice stopped him from speaking earlier. Perhaps Boaz is elderly, for he commends Ruth for not running after younger men (Rt 3:10).

Throughout the story, Ruth trusts her instincts. This is crucial in a crisis and makes it an adventure. Ruth expresses no selfdoubt. This is key to a successful outcome, especially one in which her future and the economic survival of herself and her mother-in-law are at stake. Her irregular, bold action of going alone, unbidden, to visit a single, eligible, wealthy man at night and proposing to him do not conform to accepted behaviour (also see Cook 1913:12) ${ }^{85}$ Ruth's unusual, nonconforming actions in the threshing floor scene include the following:

81.In a family story reminiscent of the Book of Ruth, my mother jokes that it took her several years of married life to learn not to approach my father with anything
important until after she had fed him. Similarly, Naomi tells Ruth to make sure Boaz important until after she had fed him. Similarly, Naomi
has eaten and drunk before she speaks to him (Rt 3:3).

82.It may also signify that Ruth, from a psychological perspective, may have completed mourning for her home, country, husband and culture and is fully ready to enter more completely into Israelite society (Walsh \& Shulman 2007:368)

83.Ruth, although poor, seems to have had a small wardrobe or at least a change of clothes (Rt 3:3).

84.Propp (1968:54) adds insights when he notes that in a story, the object of the search is obtained with the help of enticements and is caught. Ruth 3 brings a smile because readers and hearers know that Naomi actively searches for a smile because readers and hearers know that Naomi actively searches for a considered a catch and is caught!

85.Cooke (1913:12) however, refuses to judge Ruth's conduct as forward or unbecoming Why? This is because he does not know the standards of the day.
- As a foreigner, a Moabite woman but a proselyte, she asks an Israelite to marry her (see Sasson 1995:53). ${ }^{86}$

- As a woman, she propositions a man (see Martin 2008:505-507; Alter 1981:51-62). ${ }^{87}$

- As a woman, she openly shows her sexual interest in a man. ${ }^{88}$

- As a younger woman, she seeks union with an older man.

- As a nearly destitute day labourer, she seeks the wedded protection of a wealthy man.

- As a secondary owner of property through her husband's family, she seeks the financial security of a prosperous landowner.

- As a woman asking for the covering of a man, she leaves something unsaid. This covering must extend (in terms of protection and financial security) to her single dependent: her widowed mother-in-law..$^{89}$

- As a very junior, adjunct and seasonal employee, she chooses to marry her employer.

After the scene at the threshing floor, Ruth returns to Naomi. Perhaps Naomi chuckles and smiles as she listens to Ruth and gives this advice: 'Wait, my daughter, until you find out what happens. For the man will not rest until the matter is settled today'(Rt 3:18; see Greenblatt 2006:A72). ${ }^{90}$ Perhaps present at the city gate or no doubt watching anxiously at her window at her lodgings, Ruth awaits the outcome of Boaz's legal manoeuvres (see Prinsloo 1980:338). ${ }^{91}$ She and Naomi trust Boaz. They trust his judgment. The widows have put their lives and futures into his hands. They trust that he will work on their behalf. Ruth's fate rests on Israelite law.

Just as the town seemed to erupt in confusion when the two women first arrived (Rt 1:19), the town seems to erupt with joy with the news of a wedding (Rt 4:11-12). Ruth accepts blessings from the elders and the women. They, too, offer kindness to her. Actually the elders and the women speak prophetically over both Ruth and Boaz, but mainly over Ruth. The prophetic words are that she becomes an ancestress in Israel as famous as Rachel and Leah and as Tamar who bore Perez. She does. They pray that Boaz may himself become famous

86. In her two dialogues with Boaz, Ruth first describes herself as a siphah (Rt 2:13), a maidservant, and then at the threshing floor elevates herself to a 'amah (Rt 3:9). Sasson (1995:53) views the terms as 'quite distinct' and believes a siphah was the lowest rung on the social ladder whilst a 'amah could become the wife or concubine of a free man. In Chapter 2, Ruth clearly, as a gleaner, occupies the lowest job in town. In Chapter 3 on the threshing floor, she indicates, by calling herself a 'amah that she is Boaz's equal, at least in love.

87.Put in literary terminology, this is an amazing speech act. Iser (1978:55) says that 'speech acts are units of linguistic communication through which sentences are situated and take on meaning in accordance with their usage'. Ruth's command to Boaz to 'spread the corner of your garment over me' (Rt 3:9) makes her multiple meanings quite clear.

88.In mentioning this irregularity specifically, Martin (2008:505-507) points out that the threshing floor as a betrothal scene differs from the archetypes described by Alter (1981:51-62) in his classic work, The art of biblical narrative.

89.Significantly, in this second encounter, Ruth shows she remembers her first encounter with Boaz. She remembers that she first said she was a siphra. She remembers that Boaz prayed she would find shelter under the wings of the Most High. She uses the same word wing to ask that Boaz spread his garment over her (Rt 3:9). By her choice of repetitive words, she credits Boaz by knowing that he, too, thought their first encounter memorable.

90.Naomi praises Ruth for her skilful use of rhetoric, the art of verbal persuasion (Greenblatt 2006:A72).

91.Prinsloo (1980:338) believes that Boaz's conduct at the city gate is 'an example of human initiative which achieves its goal by means of a subtle strategy'. Clearly, between the encounter with Ruth at the threshing floor and the encounter with the unnamed relative at the city gate, Boaz has thought through a plan to acquire Ruth as his wife and the field of Mahlon as part of his holdings. 
in Bethlehem because of Ruth (see Loader 1994:33-34). ${ }^{92} \mathrm{He}$ does. Indeed, their prayers come true (Rt 4:11-12; see Ron 2010:85-92; Prinsloo 1980:341). ${ }^{93}$

And Naomi's neighbours, the women of Bethlehem, also join in prayer and praise, but their words also gently remind Naomi of what has happened in her life in such a short time because of God and Ruth (Rt 4:14-15). The women remind Naomi that everything about Ruth is worth more to Naomi than if she had borne seven sons. What a compliment! Whilst the elders concentrate on a large picture of prayer and blessing, the women concentrate on the small boy in Naomi's lap. They pray that he will be her kinsman-redeemer, that he will renew her life and sustain her in her old age. They remind Naomi that Ruth, her daughter-in-law, loves her. This is the only mention in the biblical text of the love of a daughter-in-law for her mother-in-law.

\section{Conclusion}

Through these multiple ways, the text shows Ruth succeeds admirably in her new life in Bethlehem (see Propp 1968:63). ${ }^{94}$ She offers generations of readers and hearers a model to follow when facing multiple crises. She gives guidelines for finding success amidst many crises and in a time of many transitions. Accepted and loved within the community, she receives the highest praise of all from the women of Bethlehem who have been completely won over by her exemplary character and her consistent, kind care of her mother-in-law. Perhaps they wish for the same treatment from their daughters-in-law! Upon the birth of a son to Ruth and Boaz, the women say to Namoi that her daughter-in-law 'who loves you is better to you than seven sons' (Rt 4:15). Indeed, that is true.

As is common throughout biblical narrative, the providence of God is actively at work behind the scenes (see Branch 2009:181-184). The Lord cares for and protects all those who come to trust under his wings (Rt 2:12). In this domestic drama of bereavement, loss, survival, adventure and extreme need stands the covenant promise to Israel from a faithful God. He fills the needs of those who trust in his divine power to save, and especially of those who treat each other in a similarly caring manner (see Matthews 2004:242).

The Book of Ruth addresses a major theme throughout Israelite literature, especially Wisdom literature: Where is God in the big questions of life and death and tragedy? On the surface, the Book of Ruth reads like an artful romance, a novella. But it is also a profound religious work that presents, in a story form, some of the major issues in Israel's religion.

92.The elders graciously bless Boaz with a prayer for his fruitfulness. The word "hayil 'also means virility and power (see Job 21:7-8; $\operatorname{Pr} 31: 3$ ). The elders' tactful blessing confirms Boaz's childlessness (see Loader 1994:33-34).

93. Ron (2010:85-92) sees numerical importance in the genealogy (Rt 4:18-22). Ron (2010:85-86) writes that ten people are listed in the genealogy; David stands in the tenth position; and the seventh person 'is Boaz, the hero of the Book of Ruth'. The seventh person in the genealogy in Genesis 5 'is the saintly Enoch', he adds. Prinsloo (1980:341) sees the genealogy as showing 'that the blessings of Yahweh are ... not to be confined to a single family but to extend much further'.

94.In terms of a literary reading, the Book of Ruth ends happily, because Boaz and Ruth marry and their son is in the kingly line of David. Propp (1968:63) notes a folktale often ends with the marriage of a hero and his ascent to the throne; in this case, it is the inclusion of Ruth, Boaz, and Obed in the line of David that shows the story's link to royalty.
For example, if there is only one God, then God is responsible for both good and evil, a concept mentioned in Isaiah 45:7 (see Bland 1981:133). ${ }^{95}$ The Book of Ruth not only lets stand Naomi's accusation of bitterness toward God over the deaths of the men and providers in her family, but also shows the kind hand of God toward her in restoration, rest, provision and the birth of a son to gladden her old age (see Bland 1981:132). ${ }^{96}$

Furthermore, the theme of covenant loyalty, broadly described as hesed, establishes the royal house of David as a house built on faithfulness and supports the ending verses containing David's genealogy (4:18-22) (see Loader 1994:34). Ruth and Naomi, two women who enter the biblical text facing devastation, emerge as winners, and the narrator approves of the bold measures they take to survive (see Masenya 2004:57).

Ruth, a valiant woman, a hayil, faces her crises of bereavement, barrenness, destitution and survival with exemplary character. The enormity of the risks she repeatedly takes should not be minimised. She handles 'the new' in her life new country, new people, new customs, new job and a new status in life - without complaining. She exhibits much grace. She faces danger with resolution. She chooses to immigrate to Bethlehem, an irrevocable decision, arguably out of love for her mother-in-law and in order to provide security for her. She gives joy to her mother-in-law by giving her a son to play with. Trible (1978:181) is not extreme at all when she says that Ruth's salvation is by courage alone.

Ruth's pilgrimage clearly offers guidelines to suffering women and marginalised women and to men and women alike who are cut off from the mainstream of life by overwhelming losses and difficulties. Ruth's pilgrimage invites imitation, gives hope and affirms yet again the biblical principle that suffering ends. ${ }^{97}$ The Book of Ruth explores the biblical principle that hesed is a commitment to a loving involvement in the lives of others, a long-term commitment to helping them (see Bland 1981:136-137). Ruth learned that by extending hesed to others, God extended it to her.

Indeed, throughout the biblical text, women take charge of their own lives and reverse their present unfortunate circumstances or bad fortunes by their own hands. The story of Ruth and Naomi carries on this theme, as do the story of Esther in the book bearing her name and the story of Judith in the book bearing her name in the Apocrypha. Quite frankly,

95. Bland (1981) agrees in the sense that ' $f$ rom a biblical perspective the question that remains is not so much the source of evil (Naomi affirms that it is from God), but rather how this relates to the goodness of God and why such evils and calamities occur' (p. 133). I would temper this to note the comments of Joseph when his terrified brothers came to him in fear of their lives, because their fathe was dead and they had no protection against Joseph's wrath. Joseph said, 'Don't be afraid. Am I in the place of God? You intended to harm me, but God intended it for good to accomplish what is now being done, the saving of many lives' ( $\mathrm{Gn}$ 50:19-20).

96.Bland (1981:132) points out that in short stories and biblical storytelling alike, a key interpretative statement may be found at the end. He sees Ruth $4: 13$ as that: 'And Boaz took Ruth and she became to him a wife and he went unto her and the Lord gave unto her conception.' Their son Obed shows God's direct and affirming Lord gave unto her conception.' Their son Obed shows God's dir
guidance in the lives of Ruth, Boaz and Naomi (Bland 1981:132).

97.For example, the suffering of Job ended with the restoration of his finances and his prominence in the community; furthermore, he had additional sons and daughters (Job 42:12-17) 
scripture encourages all people - men, women and children to aggressively seek their own betterment and the betterment of others. The canonical backing for this is Psalm 56:9b: 'By this I will know that God is for me' and Romans 8:31: 'If God is for us, who can be against us? The canonical witness is that God works alongside those who work for hesed [loving kindness], holiness, justice, mercy and righteousness, and in relieving the plight of the poor.

\section{Acknowledgements Competing interests}

The author declares that she has no financial or personal relationship(s) which may have inappropriately influenced her in writing this paper.

\section{References}

Alter, R., 1981, The art of biblical narrative, Basic Books, New York, NY. PMCid:370587

Baddeley, J.L. \& Singer, J.A., 2009, 'A social interactional model of bereavement narrative disclosure', Review of General Psychology 13(3), 202-218. http://dx.doi. org/10.1037/a0015655

Bauckham, R., 1997, 'The Book of Ruth and the possibility of a feminist canonical hermeneutic', Biblical Interpretation 5(1), 29-45. http://dx.doi.org/10.1163/ $156851597 \times 00021$

Baylis, C.P., 2004, 'Naomi in the Book of Ruth in light of the Mosaic Covenant', Bibliotheca Sacra 161(644), 413-431.

Bland, D., 1981, 'God's activity as reflected in the Books of Ruth and Esther', Restoration Quarterly 24(3), 129-147.

Block D., 1999, Judges, Ruth, Broadman and Holman, Nashville, TN.

Bloomberg News Service, 2011, 'Foreclosure filing in U.S. may jump 20\% from record 2010 as crisis peaks', viewed 27 July 2011, from http://www.bloomberg.com/news/ 2011-01-13/u-s-foreclosure-filings-may-jump-20-this-year-as-crisis-peaks.html

Branch, R.G., 2009, Jeroboam's wife: The enduring contributions of the Old Testament's least-known women, Hendrickson Publishers, Peabody.

Bull, G.T., 1972, Love-song in harvest: An interpretation of the Book of Ruth, Pickering \& Inglis, Ltd., London.

Bureau of Labor Statistics, 'Economic News Release, Employment Situation Summary', viewed 07 May 2009, from www.bls.gov/news.releas/empsit.nr0.htm

Burnette-Bletsch, R., 2007, Studying the Old Testament: A companion, Abingdon, Nashville, TN.

Bush, F., 1996, Word Biblical Commentary 9: Ruth/Esther, Word Books, Dallas, TX

Campbell, E. Jr., 1985, Ruth: A New Translation with Introduction, Notes, and Commentary, Doubleday \& Company, Garden City.

CoinMill.com, n.d., The Currency Converter 2011, viewed 25 July 2011, from http:// coinmill.com/USD_ZAR.html\#USD=2.00.

Cooke G.A., 1913, The Book of Ruth in the revised version with introduction and notes, Cambridge University, Press, Cambridge.

Davis, E.F., 2009, Scripture, culture, and agriculture: An agrarian reading of the Bible, Cambridge University Press, Cambridge.

Dillard, R.B. \& T. Longman III, 1994, An introduction to the Old Testament, Zondervan, Grand Rapids, MI.

Eagleton, T., 1991, Literary theory: An introduction, University of Minnesota Press, MN.

Eco, U., 1984, The role of the reader: Explorations in the semiotics of texts, Indiana University Press, Bloomington.

Exline, J.J., Park, C.L., Smyth, J. M. \& Carey, M.P., 2011, 'Anger toward God: SocialCognitive predictors, prevalence, and links with adjustment to bereavement and cancer', Journal of Personality and Social Psychology 100(1), 129-148. http:// dx.doi.org/10.1037/a0021716, PMid:21219078

Fewell, D.N. \& Gunn, D.M., 1988, “"A son is born to Naomi!”: Literary allusions and interpretation in the Book of Ruth', Journal of the Society of the Old Testamen 40(1), 99-108. http://dx.doi.org/10.1177/030908928801304006

Fewell, D.N. \& Gunn, D. M., 1989, 'Boaz, pillar of society: Measures of worth in the Book of Ruth', Journal for the Study of the Old Testament 40 (1), 45-59. http:// dx.doi.org/10.1177/030908928901404505

Fontaine, C.R., 2008, With eyes of flesh: The Bible, gender and human Rights, Sheffield Phoenix Press, Sheffield.

Ginzberg, L., 1968, Legends of the Jews, 6 vols., Soncino, London.

Global Finance, n.d., World's Unemployment Rates 2006-2010, viewed 27 July 2011 from http://www.gfmag.com/tools/global-database/economic-data/10297-worldsunemployment-rates-2006-2010.htm|\#axzz1TLeRYjEz

Greenblatt, S., 2006, The Norton anthology of English literature, 8th edn., vol 1, WW Norton \& Company, New York, NY.

Hansbury, P., 1986, 'Reader response: Theory and practice', Reader Response in the Classroom, in C. Chew, R. DeFabio \& P. Honsbury [sic], Bound pamphlet, pp. 4-14 New York State English Council, New York, NY.
Harley, W.F. Jr., 1986, His needs, her needs: Building an affair-proof marriage, Fleming H. Revell Company, Old Tappan.

Harris, R.L., Archer, G.L. Jr. \& Waltke, B.K., 1980, Theological Wordbook of the Old Testament, vol. 2, Moody Press, Chicago. PMCid:2203817

Hess, M., 1979, Love knows no barriers, Victor Books, Wheaton.

Iser, W., 1978, The act of reading: A theory of aesthetic response, The Johns Hopkins University Press, Baltimore.

Iser, W., 1980, 'The reading process: A phenomenological approach', in Tompkins, J.P. (ed.), Reader-Response Criticism: From Formalism to Post-Structuralism, pp. 50-69, (ed.), Reader-Response Criticism: From Formalism to Post-Structu

Iser, W., 1984, 'The reading process: A phenomenological approach', in in Tompkins, J.P.' (ed.), Reader-response criticism: From formalism to post-structuralism, pp. 50-69, The Johns Hopkins University Press, Baltimore.

Jordaan, P.J., 2006, 'An interdisciplinary approach: Reading Ruth as therapeutic narrative', Theologia Viatorum: Journal of Theology and Religion in Africa 30(1), 1-24.

Kim, Y. \& Grant, D., 1997, 'Immigration patterns, social support, and adaptation among Korean immigrant women and Korean American women', Cultural Diversity and Mental Health 3(4), 235-245. http://dx.doi.org/10.1037/1099-9809.3.4.235, PMid:9409069

Linafelt, T., 2010, 'Narrative and poetic art in the Book of Ruth', Interpretation 64(2), 117-129. http://dx.doi.org/10.1177/002096431006400202

Loader, J.A., 1994, 'David and the matriarchs in the Book of Ruth', In die Skriflig 28(1), 25-35.

Lostracco, J. \& Wilkerson, G., 1998, Analyzing Short Stories, 4th edn., Kendall/Hunt Publishing Company, Dubuque.

Lucas, E.C., 2003, Exploring the Old Testament: A guide to the psalms \& wisdom literature, InterVarsity Press, Downers Grove.

Mancini, A.D., Bonanno, G.A. \& Clark A.E., 2011, 'Stepping off the hedonic treadmill: Individual differences in response to major life events', Journal of Individual Differences 32(3), 144-152. http://dx.doi.org/10.1027/1614-0001/a000047

Martin, M.W., 2008, 'Betrothal journey narratives', Catholic Biblical Quarterly 70 (3), 505-523.

Masenya, M., 2004, 'Struggling with poverty/emptiness: Rereading the Naomi-Ruth story in African-South Africa', Journal of Theology for Southern Africa 120, 46-59. Matthews, V.H., 2004, Judges and Ruth, Cambridge University Press, Cambridge.

McManus, D., 2009, 'Dispatches', The Sunday Independent, 26 April, p. 14.

Nairne, J.S., Thompson, S.R. \& Pandeirada, J.N.S., 2007, 'Adaptive memory: Survival processing enhances retention', Journal of Experimental Psychology: Learning,
Memory, and Cognition 33(2), 263-273. http://dx.doi.org/10.1037/02787393.33.2.263, PMid:17352610

O' Kane, M., 2010, 'The Iconography of the Book of Ruth', Interpretation 64(2), 130145.

Ostriker, A., 2002, 'The Book of Ruth and the love of the land', Biblical Interpretation 10(4), 343-358. http://dx.doi.org/10.1163/15685150260340734

Perry, A., 2009, 'The veteran: Trevor Manuel has guided South Africa from bust to boom', Time, p. 24, 06 April 2009.

Prinsloo, W.S., 1980 'The theology of the book of Ruth', Vetus Testamentum 30, 330341. http://dx.doi.org/10.1163/156853380X00254

Propp, V., 1968, Morphology of the foktale, 2nd edn., University of Texas Press, Austin TX. PMCid:297379

Ron, Z., 2010, 'The genealogical list in the Book of Ruth: A symbolic approach', Jewish Bible Quarterly 38(2), 85-92.

Roop, E.F., 2002, Ruth, Jonah, Esther, Herald Press, Scottdale.

'Ruth, Book Of', 1971, Encyclopaedia Judaica 14, 518-524.

Sakenfeld, K.D., 1999, Interpretation: A Bible commentary for teaching and preaching Ruth, John Knox Press, Louisville, KY.

Sakenveld, K.D., 2002, 'At the threshing floor: Sex, reader response, and a hermeneutic of survival', Old Testament Essays 15 (1), 164-178.

Sasson, J.M., 1995, Ruth: A new translation with a philological commentary and a formalist-folklorist interpretation, Sheffield Academic Press, Sheffield.

Schwartz, S.J.R.S., Weisskirch, B.L., Zamboanga, L.S., Ham, I.J.K., Park, S.Y., Kim, et al., 2011, 'Dimensions of acculturation: Associations with health risk behaviors among college students from immigrant families', Journal of Counseling Psychology 58(1), 年

Scioli, A., Ricci, M., Nyugen, T., \& Scioli, E.R., 2011, 'Hope: Its nature and measurement', Psychology of Religion and Spirituality 3(2), 78-97. http://dx.doi.org/10.1037/ a0020903

Siquans, A., 2009, 'Forgiveness and poverty in the Book of Ruth: A legal way for a poor foreign woman to be integrated into Israel', Journal of Biblical Literature 128 (3) $443-452$.

Sutskover, T., 2010, 'The Themes of Land and Fertility in the Book of Ruth', Journal for the Study of the Old Testament 34(3), 283-294. http://dx.doi.org/10.1177/ 0309089210363033

Trading Economics, n.d., South Africa Unemployment Rate 2011, viewed 27 July 2011 from http://www.tradingeconomics.com/south-africa/unemployment-rate.

Trading Economics, n.d., United States Unemployment Rate 2011, viewed 25 July 2011, http://www.tradingeconomics.com/united-states/unemployment-rate.

Trible, P., 1978, God and the rhetoric of sexuality, Fortress, Philadelphia, PA.

Van Dyk, A.C. \& Van Dyk, P.J., 2002, 'HIV/AIDS in Africa: Suffering women and the theology of the Book of Ruth', Old Testament Essays 15(1), 2009-2024.

Walsh, S.D. \& Shulman, S., 2007, 'Splits in the Self following immigration: An adaptive defence or a pathological reaction?', Psychoanalytic Psychology 24(2), 355-372. http://dx.doi.org/10.1037/0736-9735.24.2.355

Westermann, C., 1999, 'Structure and intention of the Book of Ruth', Word \& World 19(3), 285-302. 